\title{
Tendencje rozwojowe układów sterujących hamowaniem pojazdów kolejowych
}

\begin{abstract}
$W$ artykule przedstawiono tendencje rozwojowe układów sterujacych hamowaniem pojazdów kolejowych i prace naukowo-badawcze realizowane $w$ ostatnich latach przez IPS Tabor w zakresie urzadzeń pneumatycznych, elektrycznych i elektronicznych tworzacych te uktady.
\end{abstract}

\section{Wstęp}

We współczesnych układach hamulcowych pojazdów kolejowych znajdują zastosowanie różne rodzaje hamulców: cierny klockowy lub tarczowy, magnetyczny szynowy (cierny lub na prądy wirowe), elektrodynamiczny. Hamulce te sterowane są na drodze pneumatycznej i elektrycznej. W nowoczesnych pojazdach szynowych wszystkie te rodzaje hamulców i układy ich sterowania składają się elementów pneumatycznych, elektrycznych i elektronicznych. W artykule został przedstawiony kierunek rozwoju układów sterowania hamulcami zmierzający do integracji złożonych, mechatronicznych układów w postaci modułów.

\section{Rys historyczny rozwoju układów hamulcowych}

W przeszłości systemy sterowania hamulcami pojazdów trakcyjnych zbudowane były z wielu pojedynczych aparatów pneumatycznych rozmieszczonych w różnych miejscach pojazdu podłączonych bezpośrednio do instalacji pneumatycznej. Utrudniało to dostęp do nich, uniemożliwiało realizowanie łatwej diagnostyki uszkodzeń systemu, wydłużało czas naprawy i przestoju pojazdu a co za tym idzie powodowało znaczne koszty budowy i eksploatacji. Mimo to rozwiązanie takie było stosowane ze względu na prostote ówczesnych układów. W miarę rozszerzania zakresu zadań następował wzrost skomplikowania układów hamulcowych. Ich rozwój na początku XX wieku oprócz prac nad poszczególnymi aparatami i systemami, polegał na wprowadzeniu dla poszczególnych aparatów wsporników połączonych trwale z instalacją pneumatyczną pojazdu, co umożliwiało łatwiejszy demontaż poszczególnych aparatów układu. Spowodowało to poprawę dostępności do aparatów i skrócenie postojów pojazdu związanych $\mathrm{z}$ naprawą systemu hamulca.

Dalszy rozwój układów hamulcowych polegał na integracji aparatów hamulcowych na pojeździe.
Pierwszym krokiem integrującym było ich zgrupowanie w jednym miejscu na pojeździe na tak zwanych ramach hamulcowych (Rys.1). Aparaty hamulcowe nadal posiadały własne wsporniki, ale zgrupowane były w jednym miejscu na pojeździe, co zapewniało do nich lepszy dostęp i względną łatwość wymiany. Instalacje pneumatyczne tych układów nadal były bardzo złożone, pracochłonne w wykonaniu i drogie w utrzymaniu. Również aparaty zgrupowane w kabinie maszynisty nie umożliwiały opracowania ergonomicznego stanowiska maszynisty (Rys.2).

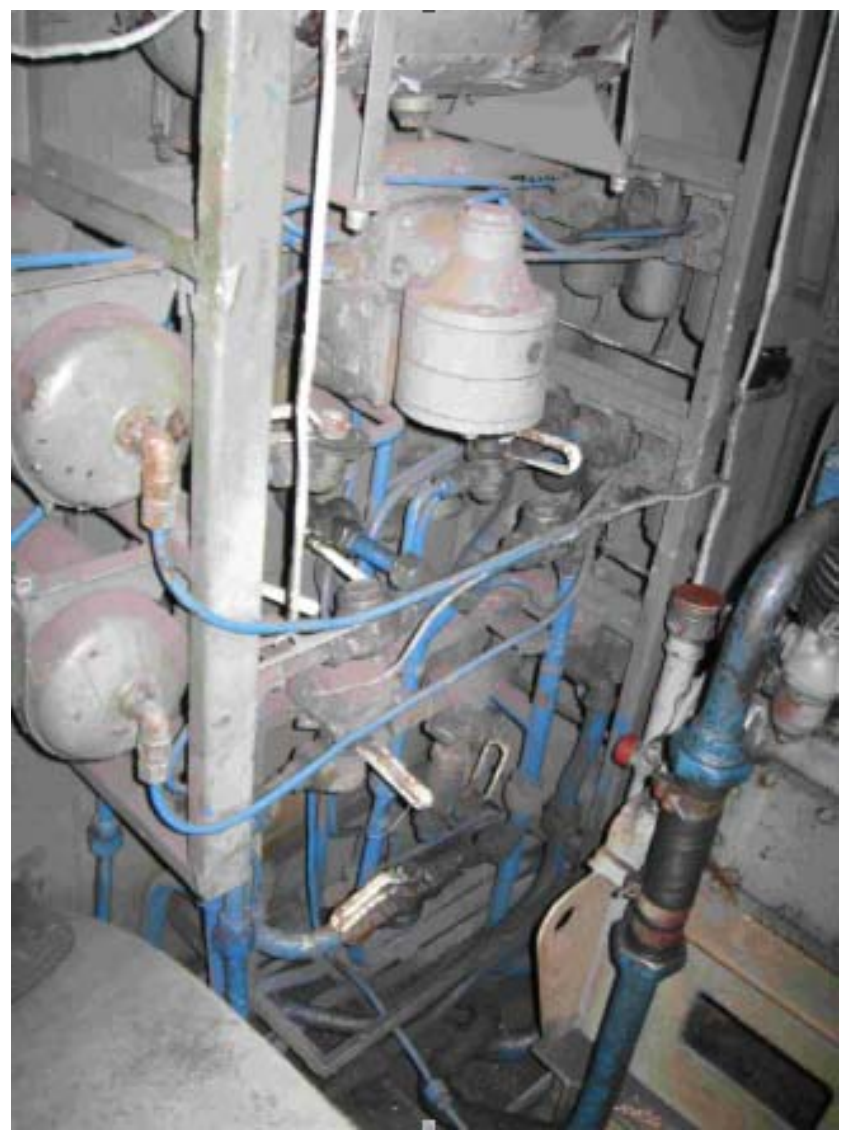

Rys. 1 Rama pneumatyczna hamulca w dotychczasowej lokomotywie ET22 


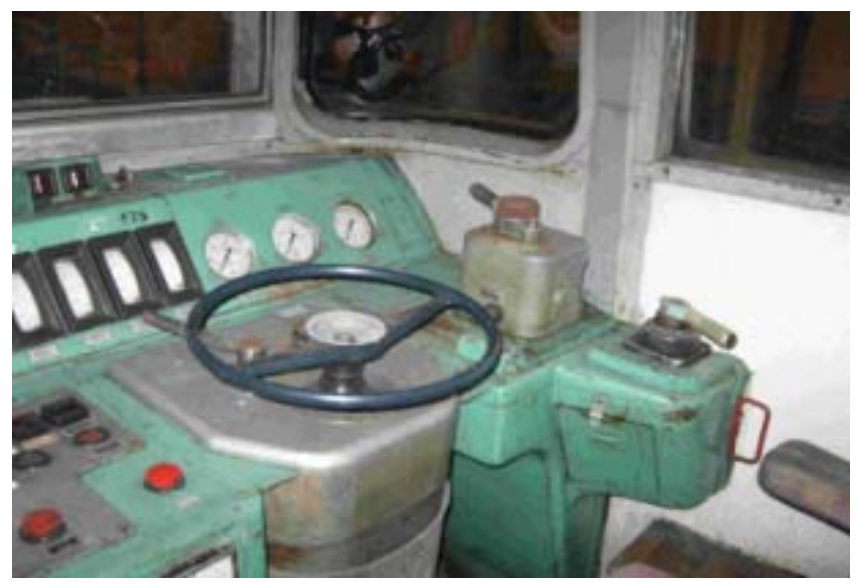

Rys. 2 Pulpit maszynisty starych lokomotyw ET22

Kolejnym krokiem w drugiej połowie XX wieku było zintegrowanie wszystkich aparatów tworzących coraz więcej i coraz bardziej złożonych systemów hamulcowych i pneumatycznych pojazdu na tak zwanych tablicach pneumatycznych. Wymagało to od producentów aparatury hamulcowej przygotowania wielu aparatów do tak zwanego montażu płytowego i opracowania nowych technologii instalacji pneumatycznej tablic, zapewniających pewne i szczelne połączenia pomiędzy dziesiątkami aparatów pneumatycznych na tablicach (Rys.3) oraz nowego systemu sterowania hamulcami i nowych manipulatorów hamulca (Rys.4).

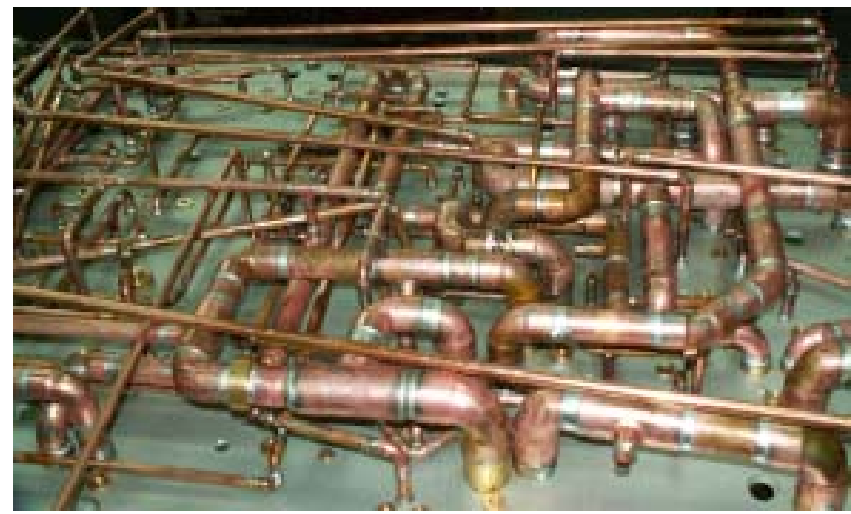

Rys. 3 Instalacja pneumatyczna tablicy pneumatycznej

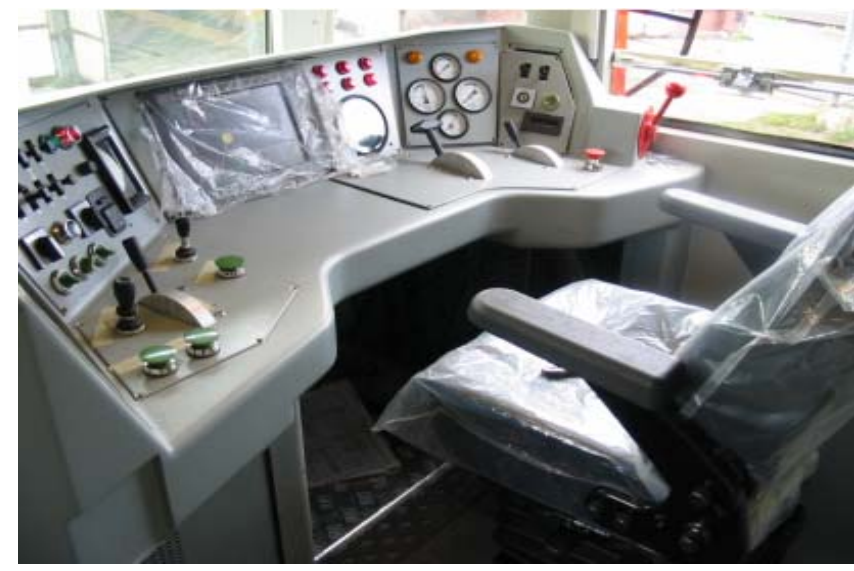

Rys. 4 Pulpit maszynisty z nowymi manipulatorami hamulca
Zintegrowanie aparatów i całych układów hamulcowych na tablicach zapewniło:

zwartą budowę układów sterowania hamulcami i rozrządu sprężonego powietrza dzięki zastosowaniu aparatów montowanych na płycie tablicy, które nie wymagały stosowania własnych wsporników i złączek

- poprowadzeniu wszystkich połączeń pneumatycznych pomiędzy tymi aparatami w korpusie tablicy oraz zintegrowanie niezbędnych połączeń elektrycznych w ramach tablicy

możliwość radykalnego uproszczenia (w porównaniu $\mathrm{z}$ układem tradycyjnym) instalacji pneumatycznej pojazdu, która łączyła teraz tablicę pneumatyczną jedynie ze zbiornikami, przewodem głównym i zasilającym oraz z cylindrami układu wykonawczego hamulca

- możliwość zaprojektowania kabiny maszynisty zgodnie z zasadami ergonomii ze względu na małe wymiary elektrycznych manipulatorów hamulca (w porównaniu z dawnymi pneumatycznymi zaworami maszynisty) i niewielką ilość przewodów powietrznych niezbędnych do poprowadzenia w kabinie maszynisty

możliwość regulacji, sprawdzenia i odbioru kompletnych układów hamulcowych i pomocniczych (zgrupowanych na tablicy) poza pojazdem a następnie - szybkiej i łatwej zabudowy tak przygotowanej tablicy w pojeździe

dogodne warunki obsługiwania aparatów zabudowanych na tablicy ze względu na czytelny ich układ, bardzo dobry dostęp oraz łatwość ich demontażu i ponownego montażu.

\section{Modulowe systemy hamulcowe}

Pod koniec XX wieku w związku $\mathrm{z}$ rozwojem układów mikroprocesorowych zastosowanych w układach sterowania hamulcami pojazdów szynowych, wystapiła możliwość uproszczenia części sprzętowej (pneumatycznej i elektrotechnicznej) układów hamulcowych, wprowadzenia zaawansowanej diagnostyki i dalszej integracji układów. Każdy z modułów jest urządzeniem mechatronicznym.

Światowe firmy produkujące wyposażenie hamulcowe rozpoczęły produkcję tak zwanych modułów hamulcowych tworzacych Modułowe Systemy Hamulcowe (MBS - Modular Brake Systems) realizujących funkcje poszczególnych układów hamulcowych lub pneumatycznych pojazdu. Moduły takie mogą być instalowane na pojeździe kolejowym w sposób zdecentralizowany, lub mogą być zintegrowane na tablicach pneumatycznych $\mathrm{z}$ łatwo dostępnymi elementami wykonawczymi oraz punktami pomiarowymi. Modułowe Systemy Hamulcowe charakteryzują się:

- kompaktową budową układu złożonego z podzespołów (submodułów) spełniających aktualne wymagania kart UIC i norm UE 
- prostą architekturą z punktu widzenia użytkownika dzięki połączeniu bardzo wielu elementów w kompaktowe moduły

- prostą instalacją typu plug-\&-play

- możliwością zaawansowanej diagnostyki (usterka jest natychmiast lokalizowana, a wadliwy moduł może być w prosty sposób wymieniony) - zapewniając wysoki stopień bezpieczeństwai

- wysokim poziomem dyspozycyjności (daily utilisation factors) pojazdu dzięki małej awaryjności i bardzo krótkim czasem niezbędnym do utrzymania i napraw systemu (wymiana wadliwych modułów)

- istotnym zredukowaniem ilości przewodów elektrycznych dzięki komunikacji zrealizowanej $\mathrm{w}$ oparciu o magistrale danych

- uproszczonymi interfejsami (wejścia wyjścia) modułów

- dużą ekonomicznością dzięki zastosowaniu dużej liczby uniwersalnych elementów dla różnych typów pojazdów i niskimi kosztami cyklu życia układów (LCC)

- możliwością adaptowania do szczególnych wymagań użytkownika i warunków eksploatacyjnych

- możliwością wprowadzania nowych funkcji, które mogą być dodawane do systemu jedynie poprzez aktualizację oprogramowania, bez konieczności zmian sprzętowych systemu.

Systemy hamulca oparte na modułach zaczęły być produkowane m.in. przez czołowych europejskich producentów aparatury hamulcowej (Faiveley i Knorr-Bremse). Każdy z producentów realizuje swoje indywidualne pomysły $\mathrm{w}$ zakresie podziału na moduły, oprogramowania, sygnałów wejściowych i wyjściowych poszczególnych modułów, systemów komunikacji (transmisji danych), wymiarów gabarytowych, sposobów mocowania i połączeń. Te modułowe systemy hamulca stosowane sa już w ostatnich latach na wielu nowych pojazdach w Europie (lokomotywach spalinowych i elektrycznych oraz wagonach zespołów trakcyjnych).

\section{Prace prowadzone przez IPS Tabor}

W ubiegłym wieku IPS Tabor przystapił do szeroko zakrojonych prac badawczo-rozwojowych w dziedzinie układów sterujących hamulcem. W latach siedemdziesiatych i osiemdziesiątych prowadzono prace nad czysto pneumatycznymi układami w oparciu o aparaturę licencyjną Oerlikona produkowaną przez Bumar-Fablok. Podjęto próby opracowania ujednoliconych zaworów rozrządczych. Zadanie polegało na opracowaniu zaworu rozrządczego $\mathrm{z}$ nowoopracowanym ogranicznikiem ciśnienia, który charakteryzowałby się ujednoliconym czasem napełniania zbiorników pomocniczych bez względu na ich zróżnicowaną pojemność i ujednoliconych czasów napełniania i luzowania cylindrów bez względu na ich wielkość. Opracowano dokumentację, wykonano i przebadano z wynikiem pozytywnym prototypy zaworów rozrządczych. Przemysł nie podjął ich produkcji.

W tym samym czasie, w wyniku zmiany wymagań w karcie UIC 541-1 [ 1] dla kurków końcowych i przewidywanej konieczności ich wymiany $\mathrm{w}$ taborze wagonowym dopuszczanym do ruchu międzynarodowego po roku 1980, IPS opracował nową konstrukcję takiego kurka. Wykonano i przebadano prototypy z wynikiem pozytywnym. I w tym przypadku mimo starań przemysł nie podjął jego produkcji. IPS Tabor wówczas jako OBRPS opracował technologię jego produkcji i wdrożył z sukcesem u siebie produkcję nowego kurka końcowego. Kolejnym zrealizowanym projektem było opracowanie układu hamulca elektrodynamicznego spełniającego wymagania karty UIC 544-2 [2] dla lokomotyw EP09. Układ został opracowany we współpracy z Instytutem Elektrotechniki w Warszawie. IEL opracował układ elektryczny hamulca ED a IPS Tabor opracował układ współpracy hamulca ED z hamulcem ciernym lokomotywy (tzw. „blending"). Opracowane układy zostały wdrożone do produkcji w IEL, OBRPS a zamontowane na wszystkich lokomotywach EP-09 przez Pafawag.

W wyniku osiagniętych sukcesów IPS Tabor rozpoczął intensywne prace naukowo- badawcze i rozwojowe nad nowoczesnymi układami hamulcowymi dla krajowego przemysłu taboru kolejowego.

W pierwszym etapie podjęto prace nad wytyczeniem ogólnych kierunków rozwoju układów sterujących hamulcami pojazdów szynowych, które zgodne byłyby z linią rozwoju realizowanego w Europie i na świecie. Pod koniec ubiegłego wieku kierunkiem rozwoju była integracja układów hamulcowych na tablicach pneumatycznych. W związku $\mathrm{z}$ tym prace naukowo-badawcze i rozwojowe w IPS Tabor rozpoczęto od opracowania pojedynczych aparatów pneumatycznych, których budowa umożliwiała w przyszłości integrację rozproszonych na pojeździe elementów i układów na tablicach pneumatycznych. Na pewnym etapie prace te wspomagane były przez Komitet Badań Naukowych w ramach projektu nr 9T12C 05597C/3410 Integrator sterujacy uktadami hamulcowymi i pomocniczymi pojazdów szynowych..

$\mathrm{W}$ ramach zadań badawczo-rozwojowych tego projektu celowego opracowano:

- zoptymalizowany system konfigurowania aparatów tablicy i ich połączeń pneumatycznych wewnętrznych i zewnętrznych opatentowany przez IPS (zgłoszenie patentowe OBRPS nr P-314570),

- liczny zestaw nowych aparatów pneumatycznych i 
- elektropneumatycznych mocowanych płytowo niezbędnych do konfigurowania wybranych, zintegrowanych układów pneumatycznych przeznaczonych dla pojazdów szynowych (wagonów towarowych, nowoczesnych wagonów osobowych i pojazdów trakcyjnych),

- opracowano i wdrożono w IPS na skalę przemysłową technologię zintegrowanych systemów pneumatycznych,

- przeprowadzono kompleksowe badania nowoopracowanych aparatów pneumatycznych i pneumatyczno-elektrycznych oraz prototypowego zintegrowanego układu (tablicy pneumatycznej dla wagonu osobowego),

- zebrano wiedzę i niezbędne doświadczenie do opracowania docelowej dokumentacji zintegrowanego układu hamulca dla nowoczesnego wagonu osobowego na prędkość $200 \mathrm{~km} / \mathrm{h}$, która została opracowana w ramach prac Instytutu.

W wyniku tych prac w IPS TABOR wdrożono do produkcji nowoczesny zintegrowany układ pneumatyczny (tablice pneumatyczną) hamulca wagonu osobowego na prędkość $200 \mathrm{~km} / \mathrm{h}$. Spełnił on wszystkie międzynarodowe i krajowe wymagania stawiane takim wyrobom, zdefiniowane w przepisach międzynarodowych (karty UIC nr: 540 [3],541-5 [4], 544-1 [5], 541-06 [6] i 546 [7]) i krajowych (norma PN-K-88177 [8]).

Wewnętrzna konfiguracja połączeń pneumatycznych zrealizowana za pomocą kapilarnie lutowanych przewodów pneumatycznych (Rys.3) oraz rozłączne przyłącza pneumatyczne i elektryczne wewnętrznej i zewnętrznej instalacji tablicy umożliwiły osiagnięcie założonych $\mathrm{w}$ projekcie celowym parametrów techniczno-funkcjonalnych to znaczy:

- łatwą obsługę i utrzymanie w sprawności układów pneumatycznych pojazdu,

- bardzo łatwy dostęp do każdego z aparatów,

- przejrzysty ich układ na pojeździe,

- możliwość przebadania i odbioru kompletnego układu pneumatycznego hamulca poza pojazdem,

- łatwość i dużą szybkość wymiany poszczególnych elementów (budowa kompaktowa) i całego układu pneumatycznego wagonu $\mathrm{w}$ trakcie eksploatacji (dzięki systemowi integracji aparatów i układów),

- wyjątkową zwartość zabudowy i uproszczenie instalacji układów pneumatycznych na pojeździe,

- możliwość prowadzenia diagnostyki układów pneumatycznych na pojeździe.

W ostatnich latach w ramach prac własnych IPS TABOR i prac współ finansowanych z innymi firmami i instytucjami zrealizowano kolejny krok $\mathrm{w}$ kierunku zintegrowanych układów hamulca. Powstał mikroprocesorowy układ sterowania systemami hamulców dla zespołów trakcyjnych, w którym zintegrowano układy pneumatyczne, elektryczne, mikroprocesorowe i transmisji danych. We współczesnych zespołach trakcyjnych może znaleźć zastosowanie wiele różnych systemów hamulcowych o zróżnicowanych parametrach, które muszą być zarządzane i sterowane automatycznie przez prowadzącego pojazd w sposób zapewniający ich działanie $\mathrm{z}$ właściwym poziomem bezpieczeństwa. Te złożone zadania mogą być zrealizowane jedynie przez mikroprocesorowy układ sterowania systemami hamulca. Opracowany w IPS Tabor układ dla zespołów trakcyjnych może zarządzać i sterować:

- hamulcem podstawowym pneumatycznym zgodnym z międzynarodowymi przepisami UIC,

- hamulcem elektropneumatycznym typu bezpośredniego,

- hamulcem elektrodynamicznym,

- hamulcem szynowym magnetycznym,

- hamulcem parkingowym,

- hamulcem postojowym sprężynowym,

- współpracą w/w systemów hamulcowych a szczególnie hamulca elektrodynamicznego z hamulcami ciernymi sterowanymi elektropneumatycznie w wagonach napędnych i tocznych,

- hamowaniem podczas utrzymywania prędkości zadanej, lub hamowania pociagu na cel,

- hamowaniem podczas samoczynnego hamowania pociagu (SHP), lub zatrzymywania pociaggów na sygnał radiowy (Radio-stop),

- hamowaniem realizowanym przez zewnętrzne automatyczne systemy sterowania ruchem pociagu (KHP, lub prowadzenie pociagów bez udziału maszynisty),

- hamulcem bezpieczeństwa $\mathrm{z}$ możliwością jego „mostkowania” przez maszynistę,

- piaskowaniem,

- układem przeciw poślizgowym podczas hamowania i rozruchu (z funkcją automatycznego piaskowania) itp.

Opracowany układ sterowania składa się $\mathrm{z}$ następujących modułów: manipulatora hamulca montowanego w pulpicie maszynisty, tablicy kabinowej realizującej funkcje sterowania hamulcami pociagu i tablic wagonowych realizujących funkcje sterowania hamulcami poszczególnych wagonów (rys 5). Wdrożony układ zapewnia wymagany poziom bezpieczeństwa i redundancji zastosowanych systemów hamowania, jest mobilny i zapewnia możliwość rozszerzeń o nowe funkcje, które mogą być wymagane w przyszłości. Zastosowany może być w dowolnym zespole trakcyjnym spalinowym lub elektrycznym poczynając od niewielkich pojazdów typu autobus szynowy, poprzez zespoły trakcyjne miejskie (metro, SKM), aż po zespoły trakcyjne na duże prędkości jazdy.

Opracowany układ w swojej względnej prostocie sprzętowej i złożonym oprogramowaniu, umożliwia elastyczny dobór współdziałania wielu rodzajów hamulca i innych pneumatycznych układów zespołów 
trakcyjnych w zależności od ich indywidualnej charakterystyki i różnych wymagań stawianych takim układom w zależności od zakresu ich stosowania, lub indywidualnych wymagań klienta (przewoźnika). Opracowany mikroprocesorowy układ sterowania jest inteligentnym

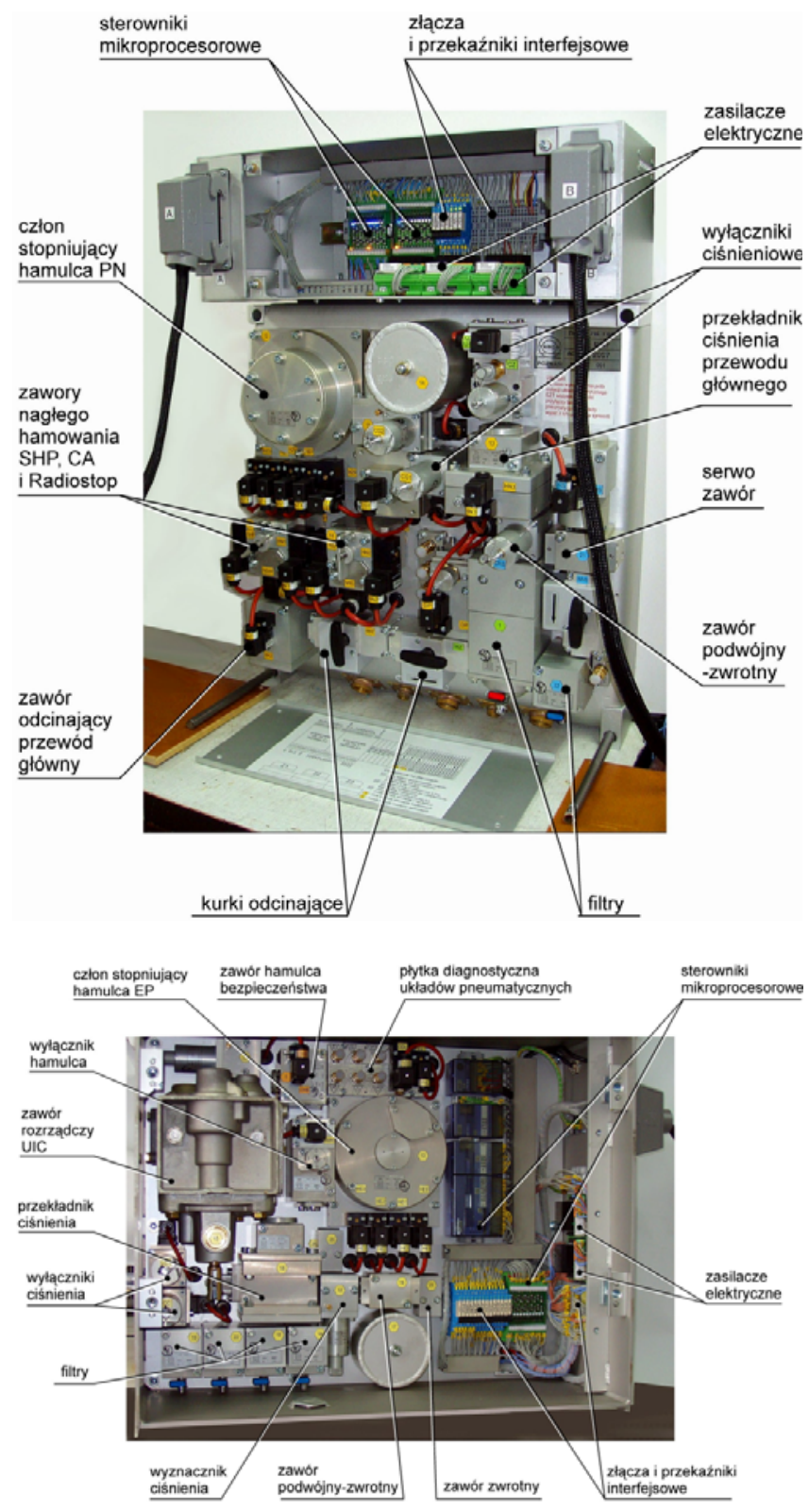

Rys. 5 Tablica kabinowa i wagonowa ezt EN57

przemysłowym systemem sterowania i zarządzania hamulcami na poziomie całego pojazdu trakcyjnego, zapewniającym integrację i współpracę wielu układów hamulcowych takiego pojazdu. Dzięki temu osiagga się następujące korzyści:

- automatyczne i bezpieczne zarządzanie wieloma układami hamulca pojazdu wieloczłonowego,

- umożliwienie sterowania hamulcami wieloczłonowego pojazdu w układzie prędkości zadanej i hamowania na cel w całym zakresie zmienności parametrów eksploatacyjnych,
- uproszczenie sprzętowych układów hamulcowych i zapewnienie możliwości elastycznych zmian w układzie poprzez zmianę oprogramowania, w zależności od zakresu zastosowania czy wymagań przewoźnika,

- zmniejszenie kosztów eksploatacji pojazdu poprzez zmniejszenie zużycia kół oraz wstawek hamulcowych lub okładzin ciernych, na skutek przejęcia istotnej części energii pojazdu przez hamulce dynamiczne w możliwie największym zakresie parametrów eksploatacyjnych,

- oszczędności wynikające z hamowania elektrodynamicznego z odzyskiem energii,

- poprawę poziomu bezpieczeństwa jazdy ze względu na możliwość automatycznego wykorzystania różnych rodzajów hamulców, samoczynnego ich uzupełniania się lub zastępowania, wielopoziomową redundancję sterowania hamulcami, oraz uproszczenie obsługi złożonego układu hamulca do jednego manipulatora obsługiwanego przez maszynistę.

Przedstawiony układ sterowania hamulcami powstał w ramach prac własnych IPS TABOR i w wyni$\mathrm{ku}$ realizacji projektów badawczych: finansowanego przez Ministerstwo Nauki i Informacji (projekt $\mathrm{nr}$ 9T12C 01018 „Opracowanie $i$ wybór na podstawie badań systemu mikroprocesorowego sterowania wielosystemowymi układami hamulców pojazdów szynowych" ) i finansowanego przez Ministerstwo Edukacji i Nauki (projekt nr 4T12C 01530 „Mechatroniczny system współdziałania wielu układów hamulca zespolów trakcyjnych"). Wyniki tych prac naukowobadawczych zostały wykorzystane i wdrożone w następujących pojazdach:

- w ezt 15WE produkcji Pesa Bydgoszcz (oznaczenie kolejowe ED59), który jest dopuszczony do ruchu $\mathrm{i}$ od kilku lat jest $\mathrm{z}$ powodzeniem eksploatowany przez Przewozy Regionalne PKP w Łodzi,

- w dwu modernizowanych przez ZNTK Mińsk Mazowiecki ezt 6WEc (oznaczenie kolejowe EW60) dla Kolei Mazowieckich przekazanych do ruchu w maju 2008 roku,

- w wielu ezt EN57 (22 szt.) modernizowanych od 2007 r. przez ZNTK Mińsk Mazowiecki i NEWAG Nowy Sącz dla: SKM Gdynia, SKM Warszawa, dla Kolei Mazowieckich i innych kolei regionalnych.

Kolejnym tematem w ramach którego IPS Tabor dokonał integracji elementów układu hamulcowego była modernizacja lokomotywy ET22 realizowana przez ZNLE Gliwice. W ramach tego tematu dokonano kolejnego kroku w kierunku dalszej integracji układów pneumatycznych lokomotyw. Polegała ona na tym, że na lokomotywach zastosowano tak zwany „kontener hamulcowy” pokazany na rys. 6. „Kontener" jest zespołem o wysokim stopniu integracji urządzeń pneumatycznych, elektrycznych i elektronicznych sterowanych za pośrednictwem sterownika pneumatyki komunikującego się z głównym sterow- 
nikiem lokomotywy. Jest to zespół lokomotywy, w którym oprócz aparatów i urządzeń zgrupowanych na tablicach pneumatycznych zabudowane zostały urządzenia do wytwarzania, uzdatniania i gromadzenia sprężonego powietrza wykorzystywanego w układzie pneumatycznym lokomotywy i prowadzonego przez nia pociagu oraz w systemy sterowania innymi układami pomocniczymi. Można go stosować w lokomotywach, w których sterowanie hamulcami i rozrządem powietrza $\mathrm{z}$ aktywnego stanowiska maszynisty odbywa się za pośrednictwem sygnałów elektrycznych. Kontener systemu pneumatycznego może znaleźć zastosowanie w elektrycznych lokomotywach liniowych,

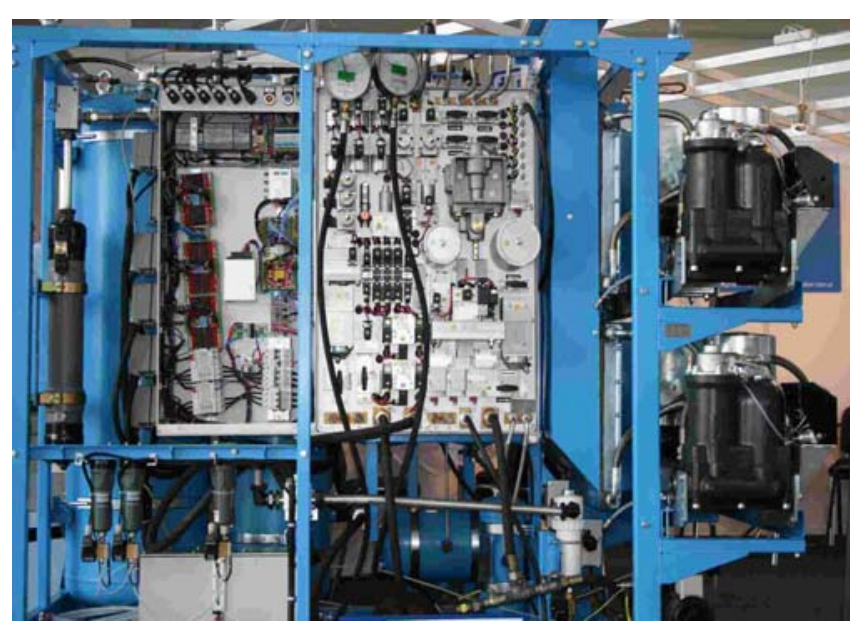

Rys. 6 „Kontener” pneumatyczny lokomotywy ET22

a po niewielkich adaptacjach może także być zastosowany w lokomotywach spalinowych. Kontener jest modułem autonomicznym, w którym możliwe jest uruchomienie i wszechstronne sprawdzenie wspó1działania wszystkich układów i urządzeń przed jego zabudowa na lokomotywie. Gotowy, sprawdzony kontener zabudowany $\mathrm{w}$ dogodnym technologicznie momencie $w$ nowobudowanej lub modernizowanej lokomotywie po jego połączeniu z układami pneumatycznym i elektrycznym lokomotywy zapewnia natychmiast bez żadnych regulacji i szczegółowych prób prawidłowe działanie wszystkich jego układów.

W kontenerze zabudowano dwie sprężarki śrubowe opracowane i wyprodukowane przez IPS Tabor, napędzane wysokosprawnymi silnikami na napięcie $3 \times 400$ VAC w klasie izolacji H. Dzięki sterowaniu sprężarkami za pośrednictwem sterownika pneumatyki zabudowanego $\mathrm{w}$ tablicy pneumatycznej, ilość dostarczanego przez nie powietrza dostosowana jest do aktualnego zapotrzebowania (praca jednej lub dwu sprężarek) przy zapewnieniu przez układ sterowania jednakowego, sumarycznego czasu pracy każdej ze sprężarek. Współpraca sterownika pneumatyki z układami łagodnego rozruchu (ang. softstart), zabudowanymi również $w$ części elektrycznej tablicy pneumatycznej zapewnia sprężarkom głównym długą żywotność dzięki łagodnym rozruchom i wyłączeniom oraz ciagłej, automatycznej ich diagnostyce.
Zastosowanie do osuszania powietrza bardzo skutecznego bezobsługowego osuszacza membranowego współpracującego $\mathrm{z}$ zestawem cyklonów i filtrów eliminuje przedostawanie się skroplin do układu pneumatycznego pociagu. Skropliny te, dzięki zaworom odwadniającym uruchamianym sekwencyjnie przez sterownik pneumatyki gromadzone sa w specjalnym zbiorniku zabudowanym w kontenerze i usuwane okresowo z zachowaniem zasad ekologii.

Zbiorniki główne lokomotywy zabudowane w kontenerze zaprojektowano $\mathrm{w}$ ten sposób, że można je połączyć ze zbiornikami zabudowanymi w lokomotywie, co umożliwia dostosowanie sumarycznej pojemności tych zbiorników do zapotrzebowania wynikającego z mocy i przeznaczenia lokomotywy. Ponadto w bezpośrednim sąsiedztwie tablicy pneumatycznej znajdują się wszystkie zbiorniki niezbędne do współpracy z urządzeniami tablicowymi.

Urządzenia zgrupowane na tablicy pneumatycznej umożliwiają sterowanie hamulcem zespolonym pociągu i lokomotywy, hamulcem dodatkowym i sprężynowym (postojowym) lokomotywy oraz rozrządem powietrza dla wszystkich pomocniczych układów pneumatycznych lokomotywy (piasecznice, smarowanie obrzeży kół, zasilanie zbiornika rozrządu i zbiornika odbieraków prądu). Tymi funkcjami steruje rozproszony mikroprocesorowy system sterowania (zabudowany w części elektrycznej tablicy pneumatycznej), którego procesory połączone są wewnętrzną tablicową magistralą danych. Dzięki zastosowaniu odpowiednich modułów wejściowych sterownik ten może przyjmować z lokomotywy sygnały o napięciu $24 \mathrm{~V}$ lub $110 \mathrm{~V}$. Wartości ciśnień w przewodzie głównym i w cylindrach hamulcowych lokomotywy są po raz pierwszy w krajowej tablicy pneumatycznej regulowane mikroprocesorowo (za pomoca cyfrowego regulatora ze sprzężeniem zwrotnym). Zespół przetworników pomiarowych ciśnienia i wyłączników ciśnieniowych podłączonych do sterownika pneumatyki zapewnia diagnostykę układu pneumatycznego lokomotywy. Tablicowy sterownik pneumatyki łączy się za pośrednictwem magistrali danych lub światłowodu ze sterownikiem lokomotywy, co umożliwia przesyłanie sygnałów diagnostycznych o stanie układu pneumatycznego hamulca i innych układów zintegrowanych na „kontenerze” do urządzeń sterujących napędem lokomotywy lub do monitora stanowiska maszynisty (panela operatorskiego). Tą drogą mogą być też przesyłane sygnały z układu utrzymującego stałą zadaną prędkość lokomotywy lub sygnały niezbędne do sterowania przez sterownik pneumatyki współpracą hamulców pneumatycznych lokomotywy z jej hamulcem elektrodynamicznym. Kontener jest połączony z układem elektrycznym lokomotywy za pomoca złączy wielopinowych (uchwyt + wtyczka), a z jej układem pneumatycznym - wyłącznie za pomoca przewodów giętkich. Zapewnia to szybki montaż i demontaż połączeń kontenera z lokomotywą. 
W kontenerze po raz pierwszy w kraju do sterowania wszystkimi funkcjami tego zespołu zastosowano układy mechatroniczne oparte na Rozproszonym Systemie Sterowania i Akwizycji (RSSA), który składa się z kilku sterowników (połączonych magistralą danych) zarządzających układami mechanicznymi, pneumatycznymi i elektrycznymi. Po raz pierwszy w tablicy pneumatycznej zintegrowano również urządzenia do zasilania sprężarek (układy softstartu, styczniki, wyłączniki nadprądowe), które dotychczas rozproszone były w różnych przedziałach lokomotywy. Dzięki zastosowaniu techniki mikroprocesorowej i integracji wielu funkcji w jednym urządzeniu uzyskano możliwość łatwego (poprzez zmiany w oprogramowaniu) dostosowania parametrów pracy kontenera do wymagań określonych przez konstruktora lokomotywy lub użytkownika.

Sterownik pneumatyki poza swoimi podstawowymi funkcjami sterowania systemami hamulców realizuje inne funkcje sterujące kontenera, z których najważniejsze to:

- sterowanie dwoma sprężarkami głównymi,

- sterowanie sprężarką pomocniczą w tym układ pneumatyczny blokad szaf wysokiego napięcia i odbieraków prądu),

- sterowanie piaskowaniem,

- wstępna likwidacja poślizgu podczas rozruchu poprzez piaskowanie i selektywne hamowanie zestawu kołowego będącego w poślizgu,

- sterowanie smarowaniem obrzeży kół,

- sterowanie zaworami układu elektrohydraulicznego (opcja),

- hierarchiczne sterowanie napędami pomocniczymi w przypadku awarii jednej przetwornicy,

- sterowanie stycznikami wentylatorów silników trakcyjnych w trybie awaryjnym,

- współpraca ze sterownikiem lokomotywy po magistrali Modbus - RTU,

- diagnostyka układów pneumatycznych i hamowania:

a/ diagnostyka pracy sprężarek,

b/ diagnostyka kontenera, wyświetlanie na panelu operatorskim stanu aparatów, wartości ciśnień i progów temperatur,

c/ diagnostyka działania manipulatorów pulpitowych,

d/ sygnalizacja na panelu operatorskim stanów awaryjnych hamulca $\mathrm{w}$ postaci odpowiednich komunikatów.

Rozproszony System Sterowania i Akwizycji (RSSA) zawierający mikroprocesorowe moduły wejść i wyjść cyfrowych oraz wejść analogowych oprócz funkcji regulacji ciśnień realizuje dodatkowe funkcje sterujące i diagnostyczne:

- przyjmowanie około 80 sygnałów binarnych,

- wysterowanie około 40 cyfrowych wyjść mocy,
- $\quad$ wysyłanie danych na złącze diagnostyczne RS232 (około 240 danych zebranych $\mathrm{z}$ całego systemu sterowania kontenera oraz wybrane dane otrzymywane ze sterownika głównego lokomotywy).

Włączenie mikroprocesorowego systemu sterowania kontenera pneumatyki w układ sterowania lokomotywy realizowane jest przez dwa konwertery. Jeden konwerter zmieniający rodzaj transmisji - CAN na Modbus - RTU i drugi konwerter zmieniający sposób transmisji - sygnał elektryczny na sygnał światłowodowy.

Rozwiązania zastosowane w kontenerze zapewniaja lokomotywie wymagany poziom bezpieczeństwa działania i redundancję sterowania hamowaniem służbowym, hamowaniem nagłym i układami pomocniczymi. Kontener został przebadany w laboratorium oraz $\mathrm{w}$ trakcie dwuletniej eksploatacji próbnej lokomotywy. Parametry kontenera spełniają wymagania odpowiednich kolejowych norm krajowych i kart grupy 540 Międzynarodowego Związku Kolei (UIC) oraz wymagania norm europejskich $\mathrm{w}$ zakresie wyposażenia elektronicznego stosowanego $\mathrm{w}$ taborze (PNEN 50155), dopuszczalnych poziomów zaburzeń elektromagnetycznych (PN-EN 55022) i badań kompatybilności elektromagnetycznej urządzeń elektrycznych (normy grupy PN-EN 61000).

Kontener systemu pneumatycznego w porównaniu $\mathrm{z}$ rozwiązaniami stosowanymi dotychczas $\mathrm{w}$ lokomotywach krajowych jest urządzeniem o dużym poziomie innowacyjności. Reprezentuje on dobry poziom europejski, porównywalny w zakresie sterowania hamulcami oraz techniki wytwarzania, uzdatniania $\mathrm{i}$ rozrządu sprężonego powietrza z rozwiązaniami oferowanymi przez firmy europejskie.

Kontener powstał w ramach prac własnych IPS „TABOR” z wykorzystaniem wiedzy zdobytej podczas realizacji w minionych latach następujących projektów badawczych finansowanych przez Ministerstwo Nauki i Szkolnictwa Wyższego :

- projekt nr 9T12C 05597C/3410 Integrator sterujacy układami hamulcowymi i pomocniczymi pojazdów szynowych.

- projekt nr 9T12C 01018,,Opracowanie i wybór na podstawie badań systemu mikroprocesorowego sterowania wielosystemowymi układami hamulców pojazdów szynowych".

- projekt nr 4T12C 01530 „Mechatroniczny system współdziałania wielu układów hamulca zespołów trakcyjnych"

- projekt nr 8 T12C 01921 ,Zastosowanie najnowszych technik informacyjnych i elektronicznych w hierarchicznych systemach sterowania i diagnozowania trakcyjnych pojazdów szynowych"

- projekt nr N 502028 31/3533,,Rozproszony system mikroprocesowego sterowania układami: napędowym, hamowania i pomocniczymi w pojazdach szynowych z napędem spalinowym" 
- projekt nr PC10T12021 2000C/5270,,Elektryczna lokomotywa towarowa średniej mocy z napędem asynchronicznym - opracowanie dokumentacji konstrukcyjnej lokomotywy, jej głównych podzespołów, wyposażenia i prototypu lokomotywy oraz wyk onania badań"

$\mathrm{Na}$ bazie osiagniętych wyników wyżej wymienionych prac naukowo-badawczych, IPS „TABOR” opracował pełną dokumentację produkcyjną kontenera i wdrożył jego produkcję w swoim Zakładzie Prototypów. Dzięki wykorzystaniu kooperacji krajowej uruchomienie produkcji odbyło się bez istotnych nakładów inwestycyjnych. Znaczącymi elementami z importu wchodzącymi w skład kontenera są jedynie stopnie sprężarek śrubowych, osuszacz membranowy, związane $\mathrm{z}$ nim filtry oraz niektóre drobne zespoły elektroniczne i elektrotechniczne.

W latach 2006-2009 IPS Tabor brał udział w pracach projektu UE pt. MODBRAKE. Obszarem zainteresowania tego projektu były moduły układów hamulcowych dla pociagów na duże prędkości, traktowane jako subsystem całego pojazdu [9], [10], [11]. Celem prac realizowanych $w$ ramach projektu MODBRAKE było opracowanie:

- specyfikacji modułów tworzących różne konfiguracje (architektury) układów hamulcowych wraz z ich analizą systemową i funkcjonalną,

- projektów modułów (w zakresie wytwarzania sprężonego powietrza, wyposażenia wózków oraz układów i urządzeń sterujących),

- procesów oceny i walidacji opracowanych modułów,

- narzędzi do oceny kosztów cyklu życia (LCC) modułów hamulca,

- wykonanie prototypów modułów i ich badania,

- przygotowanie propozycji normalizacyjnych dla CEN i CENELEC.

W realizacji tego projektu udział wzięli trzej najwięksi operatorzy kolejowi Europy (DB, SNCF i TRENITALIA), czterech producentów taboru kolejowego (Alstom, Ansaldobreda, Bombardier i Simens), dwóch największych producentów układów hamulcowych (Faiveley i Knorr-Bremse), stowarzyszenia (np. UNIFE, UIC) i europejskie ośrodki naukowe (Techniczny Uniwersytet Berlin, Politechnika w Turynie i IPS TABOR).

Wyniki prac zostały zademonstrowane w Turynie pod koniec 2009 roku na opracowanych i wykonanych prototypach modułów [12] a wnioski i propozycje standaryzacji przekazane CEN i CENELEC będa podstawą powstawania nowych norm, przez co będą miały wpływ na kierunek rozwoju układów hamulcowych w przyszłości.

\section{Wnioski}

W światowych rozwiązaniach pojazdów obserwuje się tendencję do wprowadzania modułowej budowy wszystkich układów i systemów na pojazdach. Zapewnia to $\mathrm{z}$ jednej strony podwyższone bezpieczeństwo a $\mathrm{z}$ drugiej niskie koszty LCC. Prowadzi to również do unifikacji, normalizacji modułów, co w konsekwencji powoduje spełnienie warunków technicznej interoperacyjności, ograniczenie kosztów badawczorozwojowych, zmniejszenie kosztów wdrożenia układów dla nowego pojazdu i istotne skrócenie czasu trwania tych procesów.

W przyszłości układy sterujące hamulcami składać się będą z modułów funkcjonalnych o znacznym stopniu integracji urządzeń mechanicznych, pneumatycznych, elektrotechnicznych i mikroprocesorowych powiązanych ze sobą magistralami danych. Wymagać to będzie od producentów i jednostek naukowobadawczych tworzenia interdyscyplinarnych zespołów umiejących rozwiązywać złożone zadania. Prace w zakresie mechatroniki stosowanej w pojazdach szynowych IPS Tabor aktualnie prowadzi i rozwija angażując w nie środki własne i przy wsparciu Ministerstwa Nauki i Szkolnictwa Wyższego realizując aktualnie następujące projekty:

- projekt Nr N R10 0046 06/2009 pt. „Mikroprocesorowy system przeciwpoślizgowy dla trakcyjnych pojazdów szynowych spetniajacy wymagania unijnych Technicznych Specyfikacji Interoperacyjności"

- projekt Nr 6 ZR 6 2009C/07185 pt. „System zawieszenia pneumatycznego wagonów osobowych, zespotów trakcyjnych i lekkich pojazdów szynowych z uktadem aktywnego sterowania"

- projekt Nr N R10 0048 06/2009 pt. „Mikroprocesorowy system diagnostyczny głównych systemów trakcyjnego pojazdu szynowego, uwzględniajacy ocenę bieżaca i prognozowanie stanów"

\section{Literatura}

[1] Karta UIC541-1, Hamulec Przepisy dotyczace konstrukcji różnych częśsi hamulca.

[2] Karta UIC544-2, Warunki jakie musza spetniać hamulce dynamiczne lokomotyw $i$ wagonów silnikowych.

[3] Karta UIC 540, Hamulec. Hamulce pneumatyczne dla pociagów towarowych i osobowych.

[4] Karta UIC 541-5, Hamulec. Hamulec elektropneumatyczny (hamulec ep). Elektropneumatyczne mostkowanie hamulca bezpieczeństwa.

[5] Karta UIC 544-1, Hamulec. Hamowność.

[6] Karta UIC 541-06, Hamulec. Przepisy dotyczace konstrukcji różnych części hamulca. Hamulec magnetyczny.

[7] Karta UIC 546, Hamulec. Hamulec dużej mocy dla pociagów pasażerskich.

[8] Norma PN-K-88177, Tabor Kolejowy. Hamulec. Wymagania i metody badań. 10.01.2002r.

[9] Durzyński Z.: Pojazdy z systemami modułowymi sposobem na zwiększenie konkurencyjności kolei. Konferencja QSEV 2007

[10] Kaluba M., Piechowiak T.: The european union modbrake program - interoperability and safety of railway braking systems. Konferencja QSEV 2009. Kraków

[11] Durzyński Z.: Projekty unifikacji taboru kolejowego realizowane w Unii Europejskiej. TTS nr 4/2007; str. 46-51 